\title{
RELIGION I BARNEHAGE OG SKOLE. TO DO, OR HOW NOT TO DO
}

Er yoga religionsutøvelse - og er det i så fall problematisk å bedrive i barnehagen? Enn julevandring i den lokale kirka - er det uproblematisk om et trossamfunn tar ansvaret for barnehagens pedagogiske opplegg? Og ikke minst: Hvem har makten til å definere at noe er religion eller ikke? Dette belyser Ragnhild Laird Iversen og Kari Krogstad i den første artikkelen i dette nummeret.

Artikkel nummer to gir et annerledes perspektiv på religion i barnehagen, for her er det barnehager med utvidet, kristent livssynsformål som er i søkelyset. Styrere og pedagogiske ledere forteller at både bordbønn og et stort utvalg bibelfortellinger har en integrert plass, og en siteres på at de har «påskefest og pinsefest på dagtid, der vi inviterer de som arbeider i staben [i lokalmenigheten] og foreldrene.» I artikkelen presenterer Helje Kringlebotn Sødal og Olav Hovdelien trekk ved kristne barnehager i Norge, drøfter hva som kjennetegner den kristne tradisjonsformidlingen i disse barnehagene, og lanserer begrepet «plural tradisjonsformidling» som en videreutvikling fra Sundéns dikotomi mellom verbal og total tradisjonsformidling. I praksisartikkelen Kirkeskipet skriver Svein Ellinggaard om gudstjenester for de aller minste - som også barnehagebarn inviteres til å delta i.

I tilknytning til skoler har det vært nokså mye debatt om rommet for religion/ religiøs praksis og samarbeid med Den norske kirke, blant annet knyttet til skolegudstjenester, bibelutdeling, religiøse elevgruppemøter og konfirmasjonsundervisning i skoletida. Siden barnehage ikke har det samme obligatoriske preget som skole, finnes ingen fritaksparagraf i barnehager, og plassen for religion har vært mindre offentlig debattert enn tilsvarende i skoler. Artiklene du kan lese i dette 
nummeret får tydelig fram at det ikke er helt klart og udiskutabelt hva som er god praksis knyttet til religionsformidling og religionens plass i barnehagen, verken i offentlige barnehager eller livssynsbarnehager. Sødal og Hovdelien formulerer det slik ut fra sin forskning: «Vi gir informantene rett $\mathrm{i}$ at det er krevende å skille mellom forkynnelse, som verken barnehageloven eller rammeplanen omtaler direkte, og formidling som vanligvis forbindes med pedagogisk virksomhet.» Et særpreg for barnehagen sammenliknet med skolen handler også om mulighet for kognitivt rettet opplæring med utenfra-perspektiv. Erfaring og opplevelser med alle sanser er sentralt i barnehagepedagogikken og i arbeidet med de ulike fagområdene. Artiklene i dette nummeret gir viktige perspektiver til et lite belyst felt der det er behov for videre refleksjon og forskning.

Dette nummeret bringer også et rikt utvalg artikler om religion i skolen og en praksisartikkel om samarbeid mellom kirke og skole. Rannveig Oliv Myhr belyser i sin artikkel hvordan det kan være krevende for elever å gi uttrykk for en religiøs tro i samtaler i skolen, og at det kan tolkes som en demokratisk handling å trekke seg ut av slike samtaler. Anny Holien presenterer et undervisningsopplegg om Bibelen hun som kateket holder for elever i femte klasse. Andrew J. Thomas presenterer analyser av bilder i lærebøker, og drøfter hvordan systematiske forskjeller i bildetyper kan motvirke kvalitativ likebehandling av de ulike religionene. Kåre Fuglseth og Olav Kansgar Straum bidrar med en artikkel der de kartlegger hvordan vedtaket om at lærerstudenter skal få en viss mengde religionog etikkompetanse (RLE i PEL-faget) har blitt fulgt opp. De konkluderer med at det er store sprik og fare for at framtidige lærere ikke får den kompetansen de skal ha. Nummeret inneholder også bokmeldinger som tematiserer både lærebøker, kulturarv og religion i skolen. God lesing!

Gunnfrid Ljones Øierud

Redaktør 